\title{
Development of IoT Service Classification Algorithm for Integrated Service Platform
}

\author{
Kinam Park ${ }^{*}$, Daewon Lee ${ }^{\#}$ \\ * Creative Information and Computer Institute, Korea University, Anam-ro, Seongbuk-gu, Seoul, 02841, Korea \\ E-mail:spknn@korea.ac.kr \\ ${ }^{\#}$ Dept. of Computer Engineering, Seokyeong University, 124 Seogyeong-ro Seongbuk-gu, Seoul, 02173, Korea \\ E-mail:daelee@skuniv.ac.kr
}

\begin{abstract}
Recently, with the appearance of the IoT paradigm, the existing Internet environment has changed with various things that connect with the Internet. The IoT paradigm is applied to various service such as smart homes, building management, surveillance services, smart farm, and so on. The environment of IoT services concerned on communication and interaction processes between different devices. To solve these complex problems, many researchers and service providers are focused on the integrated service platform. However, previous studies did not consider problems such as service similarity and module reusability. In this paper, we focused on the classification of services for providing reusability. And we propose classification algorithm that is based on detail operation steps of IoT services. To proof proposed classification algorithm, surveyed over 100 commercial IoT services are classified into 19 groups. The experimental results present each group is grouped together by their purpose.
\end{abstract}

Keywords - internet of things (IoT); integrated service platform; service classification; module reusability; service similarity;

\section{INTRODUCTION}

The development of wireless networks and data processing, such as wireless communications, wireless sensor networks, and cloud computing enhanced the Internet into intelligent devices. This paradigm is called Internet of Things (IoT) that the existing Internet environment has been changed with various things that connect with the Internet. It is provided the services for the user by communication between which are close to life. Unlike the existing Internet service, the IoT service aims to provide a suitable service to users rather than simply communication between devices [1], [2]. Currently, simple services are provided, but services combining various services will be developed for the future.

Most of the services are provided based on independent servers for each service, so sharing and integration management among the respective services are not performed at present. Considering the development of explosively increasing IoT devices, the integration of services and exchange data of heterogeneous services will be present [3], [4], [5], [6], [7].

From a technical point of view, to integrate and manage various services, there are several problems to solve that as follows: various sensor devices, various data types of transmission, inter-device data exchange of services and other services, integration among different types of services and so on. From a market perspective, the main problem is that most of IoT services have their own server and own operation modules. There are many similar IoT services, they couldn't share their data, module, analysis reports and so on. Depending on the single server, it causes less accessibility and various data type of each service [8], [9], [10].

To solve various problems caused by collaboration between various sensor devices and various services, a combination of various services is required to manage uniformly and an integrated service platform has been needed. If several services are performed on a single platform, there are many advantages. The most of them are reusability of modules that causes easy to develop new IoT services and approach on IoT market. However, without similarity between services, reuse of module couldn't be provided. If the platform is provided without similarity, it can't be guaranteed the module reusability.

To provide reusability, we focused on the classification of services. Our proposed classification algorithm is based on detail operation steps of IoT services. Proposed classification consists of 4 steps. The first step is sensing step that classifies sensor devices. The second step is data management. In data management step, we classify the preprocessing of data and maintenance of data. Then, the 
processing step divides and combine operation modules. Finally, in the output step, we classify IoT services into their own actions.

To proof proposed classification algorithm, we sort 37 IoT services that perform its own processing from surveyed over 100 commercial IoT services. They are classified into 19 groups. The 10 groups of them that have more than one service. By experimental analysis, each group is grouped together by their purpose.

The remainder of this paper is organized as follows. Section II presents related works of classification of IoT services and the system environment that our research based on. Section II also presents the proposed classification algorithm that based on 4 operation steps. Section III details our experimental methodology and the results alongside a detailed analysis. Finally, Section IV concludes this paper.

\section{MATERIAL AND METHOD}

\section{A. Related Works}

Recently, the environment of IoT services concerned on communication and interaction processes between different devices. The architecture of the IoT basically consists of three layers: sensing layer, network layer, and application layer.

- Sensing layer: sensing devices such as RFID tags, smart

- Network layer: collected data are transmitted, communicated, and processed

- Application layer: various functionalities of IoT such as process components, execution components, etc.

Fig. 1 shows a three-layer architecture of the IoT environment. Providing lots of IoT services, a serviceoriented platform is proposed, that a large number of service operations are involved, such as service classification, discovery

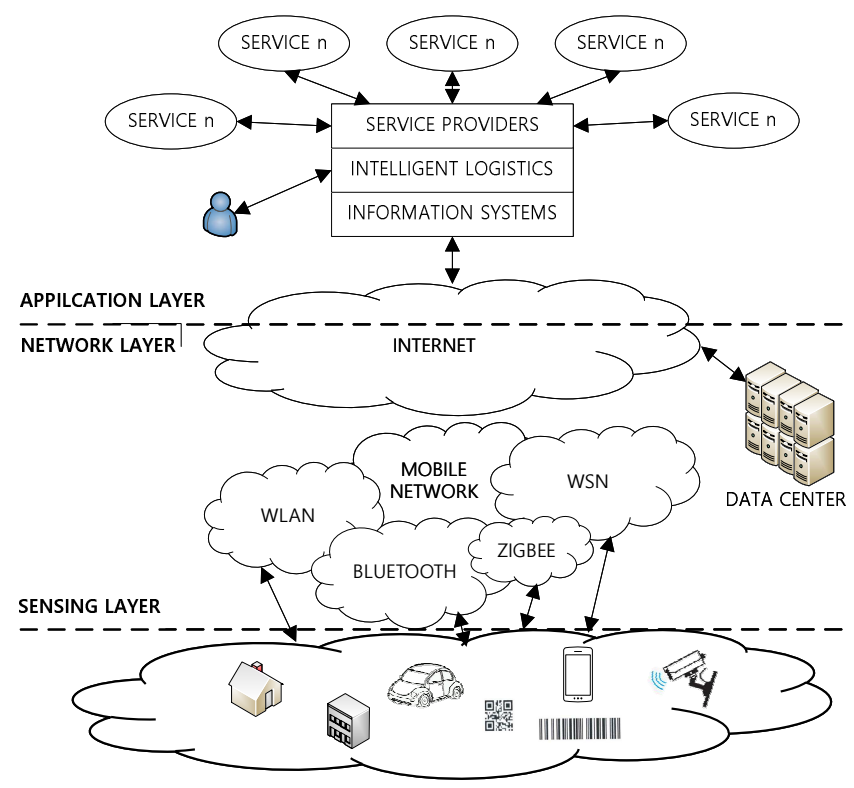

Fig. 1 Basic IoT architecture

In the previous classification criteria such as components, services, the power of devices, and sensor information have been suggested to classify Internet services.
[11] classify IoT device into 3 levels.

- Level 1: Identification and sensing devices

- Level 2: Ad-hoc device between sensor and wireless device

- Level 3: Connection device between wireless device and Ethernet

Level 1 is focused on storage and power availability. For example, simplest sensors, passive and semi-passive tags. Level 2 is focused on connection methods. For example, active tags, Zigbee full function devices. Level 3 is focused on communication method. For example, IP based, no IP based and so on. And, Fig. 2 shows the hierarchal classification of IoT service by service type into 3 levels [8].

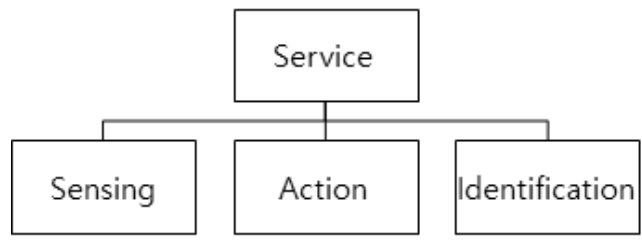

Fig. 2 Hierarchal classification of IoT service

The service is to allow or block user access and manage the following three (Sensing, Action, Identification). Sensing refers to simple sensors. For example, temperature, humidity measurement sensor and so on. The action is divided into a simple action such as on/off or a complex action. Finally, identification is a combination of version, service ID, description, and so on.

[8] classify IoT service that as follows:

- Low-level service: A set of sensors that can be consists of access devices or resources

- Resource service: A set of devices that manage sensors

- Entity service: A single service consisting of sensors and management devices

- Integrated service: An integrated service consisting of single services

The entity service is the core of IoT system that consists group of low-level services. For example, Amazon Echo, SKT Nugu, and so on. The integrated service is an IoT environment that can be organized by a group of entity services. For example, smart home, smart building, and so on.

Categorized the Internet service based on the power processing of the device. Since continuous communication of all wireless devices has a direct effect on the power of the device, a low-power, non-IP sensor connection using IoT gateway is proposed to solve this problem [13].

Zhu et al suggested the needs of open IoT platform for reusing collected and analysis data between various services. And, the common cloud based unified platform is proposed to combine several single services that depend on each single platform [7].

\section{B. System Environment}

To support various IoT services, we aim to provide an integrated platform on the public cloud. The system environment based on this study is shown in Fig. 3 .

The system environment consists of four states: sensor, environment, service group, and platform. 


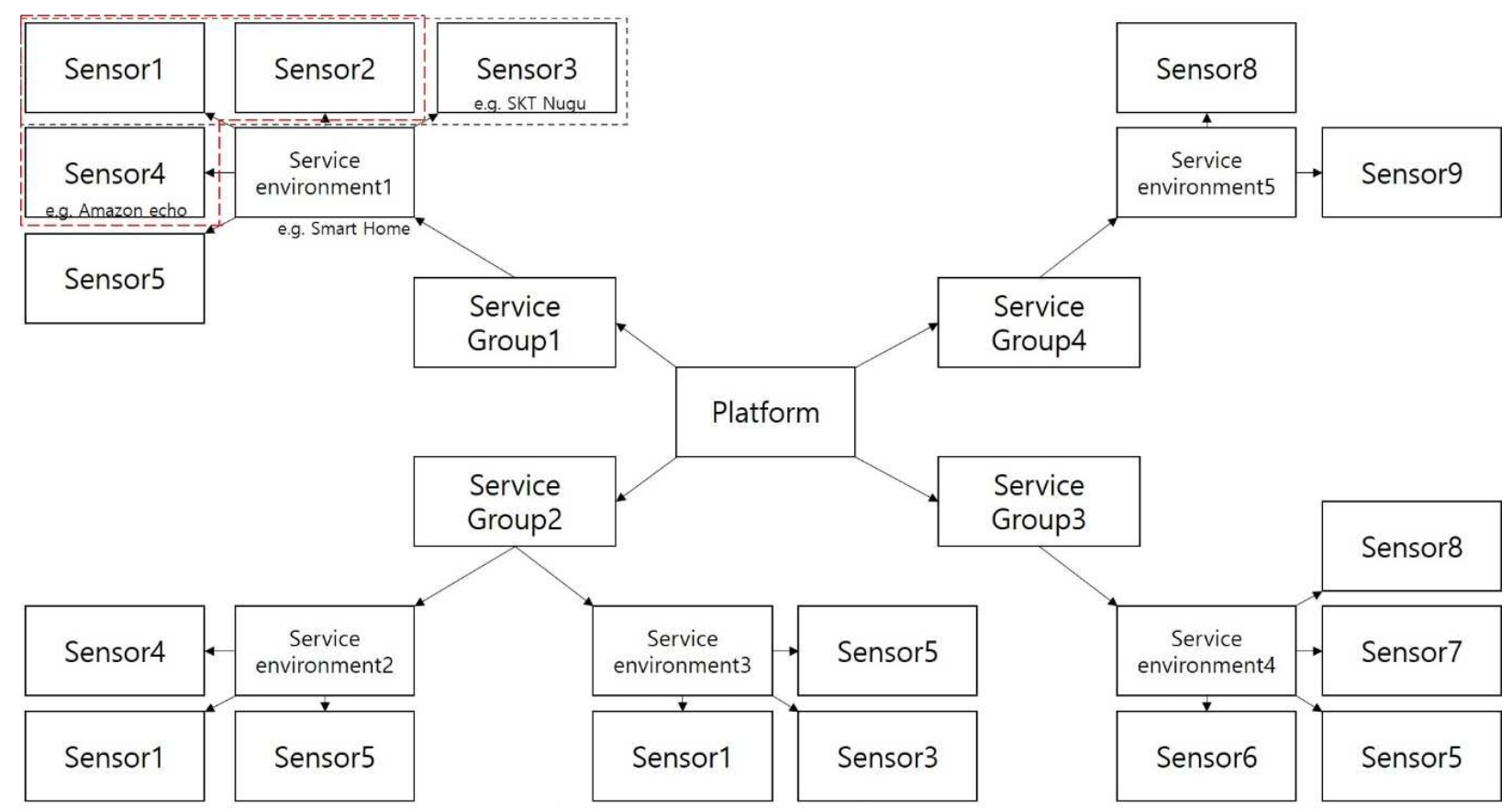

Fig. 3 System environment

- Sensor: Consists of data acquisition devices.

- Service environment: the environment in which a single service is provided, consisting of sensors and operating devices.

- Service group: Consists of various services that can be provided in the same service environment.

- Platform: Integrated management of various service groups.

In sensor state, there are lots of sensors to collect data such as heat, light, temperature, pressure, sound and so on. Each sensor could be a single low-level service such as an alert. However, low-level service couldn't satisfy the user needs. To provide adaptive service, the analysis is needed. Simple analysis can be performed on the sensor device, but complex analysis needs high performance of cloud. The service environment is a space that the complex service is provided. For example, Amazon echo returns the appropriate response or action to the user's request using the sensor inside the space. A service group is a set of services that perform a similar role. For example, Smart Home Service Group could consist of Amazon Echo, SKT Nugu, KT Jini, etc. We are willing to present an integrated platform that serves lots of services (smart home service group, smart building service group, smart farm service group, etc). By proposed integrated platform, efficiently integrated management is presented and reusability of configuration modules of each service is increased.

\section{Classification Algorithm of IoT Service}

In this section, to present efficiently integrated management and increasing reusability of configuration modules of each service, we describe classification algorithm of IoT service. The proposed service classification algorithm consists of four steps as follows. Sensing, Data management, Processing, and Output. The classification criteria for each step are as follows.

- Sensing: presence of own power/IP
- Data management: presence of data preprocessing/ maintenance

- Processing: operation modules

- Output: output actions

\section{1) Sensing Step}

There are various sensor devices gathering input data for IoT service. They perform very simple actions to complex actions. Depending on actions, they perform sensing, identification, communication with their groups, communication with the server and so on. In this step, we are focused on communication type, computation power, and battery capability. Table 1 shows classification of sensing devices and each classification criteria.

TABLE I

ClassificAtion of SENSING DeVICES AND CRITERIA

\begin{tabular}{|c|l|l|}
\hline Level & \multicolumn{1}{|c|}{ Criteria } & \multicolumn{1}{c|}{ Explanation } \\
\hline 1 & Self-power & Activate battery power \\
\hline 2 & Connect to AC/DC & $\begin{array}{l}\text { Using an external AC / DC } \\
\text { power adapter }\end{array}$ \\
\hline 3 & IP & Presence or absence of IP \\
\hline
\end{tabular}

The level 1 sensor devices are classified by their battery capability that can be rechargeable or one-time usage. The level 2 sensor devices are classified by fixed power. They are more powerful than level 1 sensor devices, but they are fixed at certain space as a fixed sensor. The level 3 sensor devices are classified by communication method. There are several communication methods such as RFID, NFC, WiFi, Bluetooth, ZigBee, GSM, 3G, LTE and so on. But, in this level, we classify them into IP and non-IP by the amount of data transmission.

\section{2) Data Management Step}

The standard of IoT service has not yet been clearly defined. To provide integrated management, the data format of IoT service should be unified. However, most of IoT 
services use their own data formats and file system. So, each data should be converted the same format to share among them. In this data management step, we are focused on the data format of transmission and maintainability of stored data. Table 2 shows classification of data management and each classification criteria.

TABLE II

ClassificATION OF DATA MANAGEMENT AND CRITERIA

\begin{tabular}{|c|l|l|}
\hline Level & \multicolumn{1}{|c|}{ Criteria } & \multicolumn{1}{c|}{ Expanation } \\
\hline 1 & Data preprocessing(client) & Preprocessing by client \\
\hline 2 & Data preprocessing(server) & Preprocessing by server \\
\hline 3 & Type of storage data & $\begin{array}{l}\text { Volatile data/ non- } \\
\text { volatile data }\end{array}$ \\
\hline
\end{tabular}

The level 1 data preprocessing is the conversion of a data format that performs at the client before data translation. The level 2 data preprocessing is the conversion of a data format that performs at client server after data translation. In other words, the preprocessing at level 1, 2 convert data into a unified format to prepare own main processing of each IoT service. At level 3, the data is classified by type of storage data. Some of IoT services keep their data to analysis, but also there are other IoT services use their data only once. In this data management step, data of IoT services are classified by preparation before their own main processing.

\section{3) Processing Step}

Most IoT services have their own analytical operations to provide services. However, these analytical operations are a combination of basic operations with their own analysis modules. Table III shows an example of basic operation.

TABLE III

CLASSIFICATION OF EXAMPLE OF OPERATION

\begin{tabular}{|c|c|l|}
\hline Level & Operation & \multicolumn{1}{c|}{ Explanation } \\
\hline 0 & Compare & Basic operation \\
\hline 0 & Sum & Basic operation \\
\hline 0 & Count & Basic operation \\
\hline 0 & Average & Basic operation \\
\hline 0 & - & - \\
\hline 1 & Set & Combination of basic operation \\
\hline 2 & ETC & Own operation of service \\
\hline
\end{tabular}

The level 0 consists of basic operations and they have no operator precedence between them. The level 1 is another operation that user defined with a combination of basic operations. It can be evolved to new operation or function. The level 3 is service dependent operation if the service needs their own analysis function.

\section{4) Output Step}

The IoT services have their own output actions that depend on their purposes. For example, the case of smart air conditioner it analysis the temperature of space by the sensor device and decide cooling down if the temperature is over threshold and request cooling down action to the air conditioner and the variation of temperature can be saved as a monthly report. Most of IoT services perform basically report their analysis, alert the situation, request action by their analysis result, and so on. Table 4 shows an example of basic action.

TABLE IV

CLASSIFICATION OF EXAMPLE OF ACTION

\begin{tabular}{|l|l|l|}
\hline Level & Action & Explanation \\
\hline 0 & Report & Basic action \\
\hline 0 & Alert & Basic action \\
\hline 0 & Action & Basic action \\
\hline 1 & ETC & Own action of service \\
\hline
\end{tabular}

\section{5) Proposed Classification Algorithm}

In this subsection, we proposed classification algorithm. As follows above classification steps, proposed algorithm is focused detail action of each step. Table 5 shows proposed classification algorithm.

TABLE V

Proposed ClASSIFICATION ALGORITHM

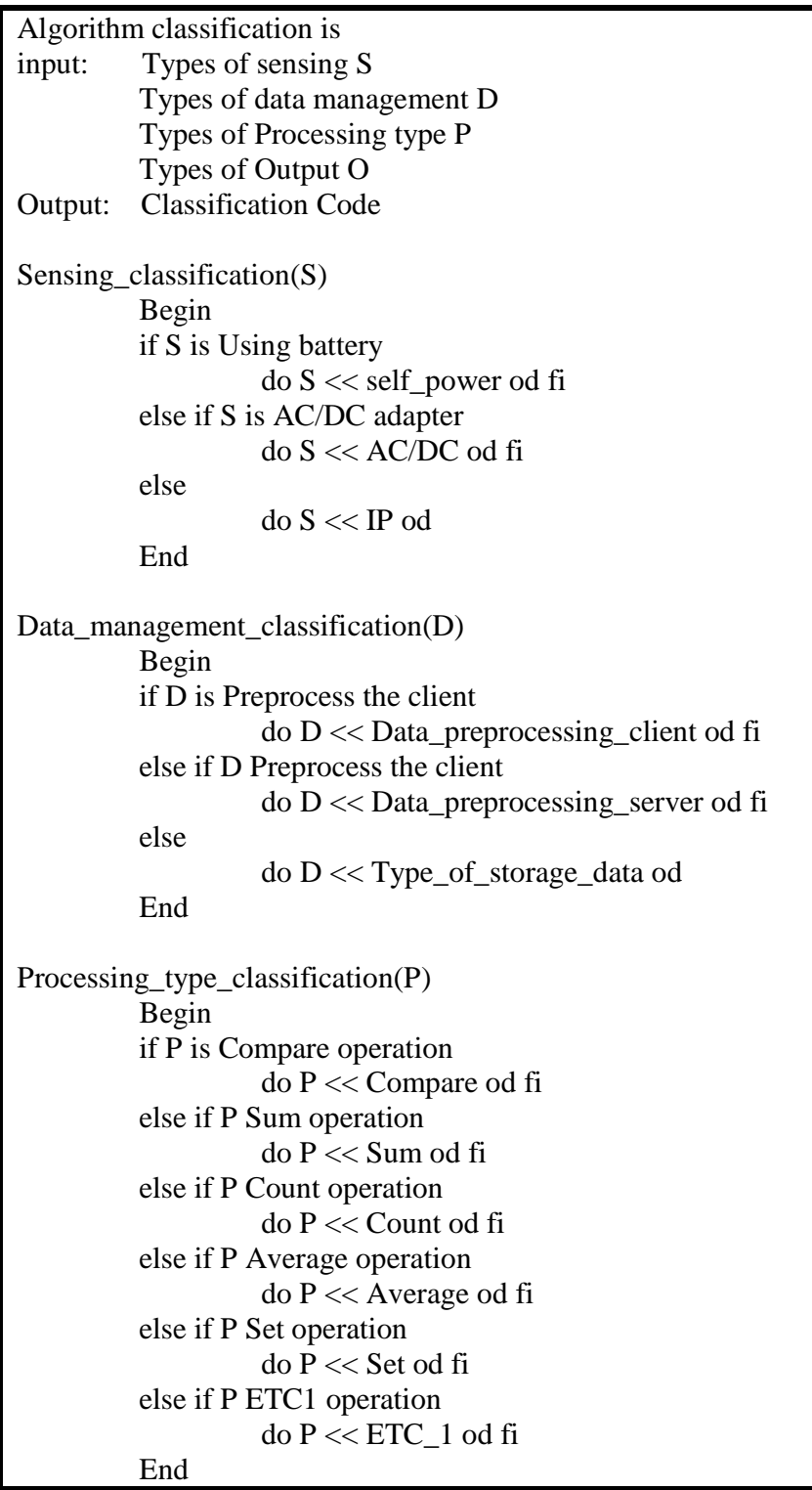




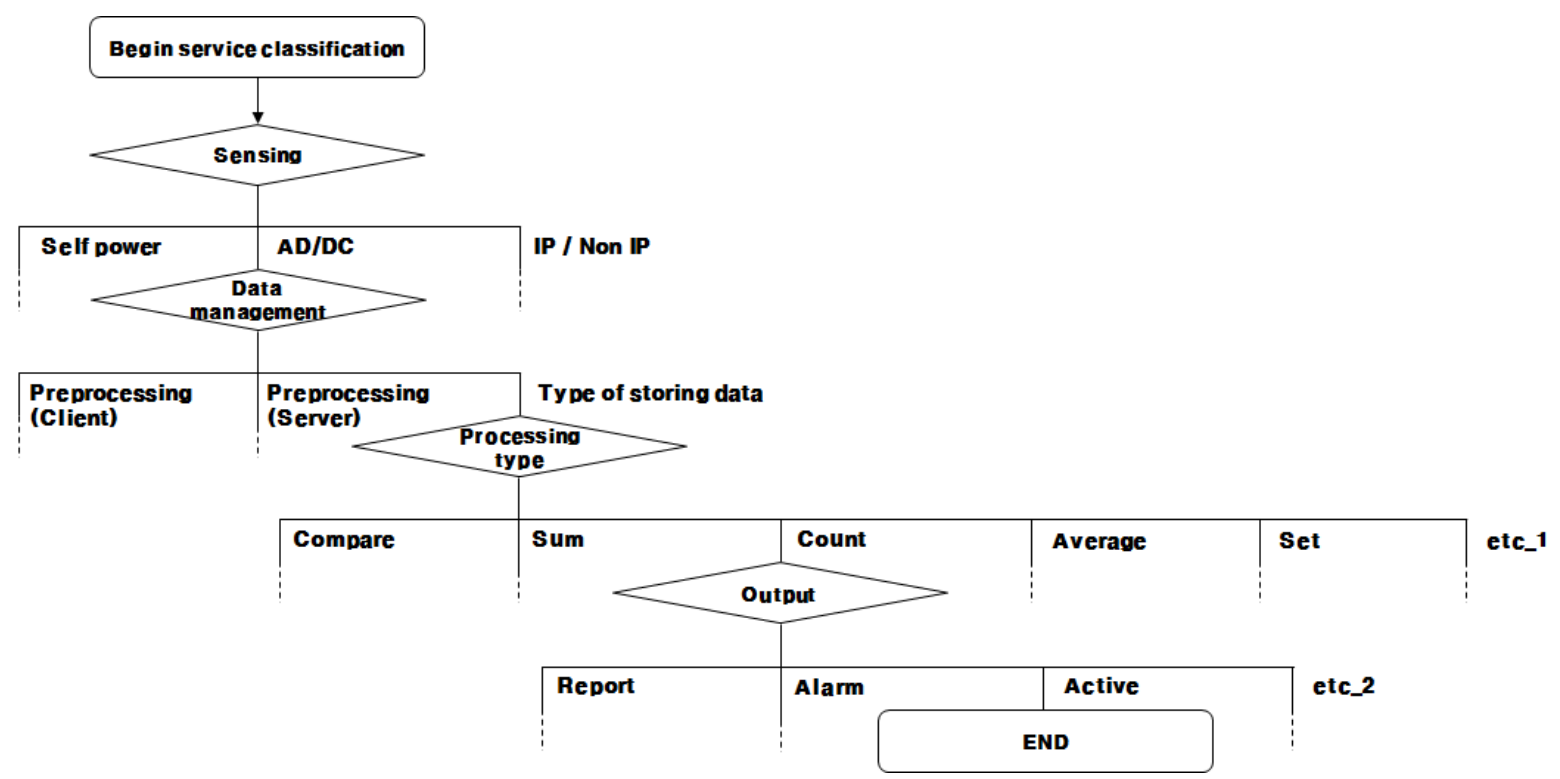

Fig. 4 Example flow of proposed classification algorithm

\begin{tabular}{|c|}
\hline $\begin{array}{l}\text { Output_classification }(\mathrm{O}) \\
\text { Begin } \\
\text { if } \mathrm{O} \text { is Report operation } \\
\text { do } \mathrm{O}<<\text { Report od fi } \\
\text { else if } \mathrm{O} \text { Alert operation } \\
\text { do } \mathrm{O}<\text { Alert od fi } \\
\text { else if } \mathrm{O} \text { Action operation } \\
\text { do } \mathrm{O}<<\text { Action od fi } \\
\text { else if } \mathrm{O} \text { ETC } 2 \text { operation } \\
\text { End } \quad \text { do } \mathrm{r}<\text { ETC_2 od fi }\end{array}$ \\
\hline
\end{tabular}

\section{RESULT AND DISCUSSION}

The experiment environment of our research is progressed on a single cluster with 4 desktops. Each one consists of Intel i7 8 cores ( 4 hyperthreaded cores included) $3.4 \mathrm{GHz}$ processor, 16GB memory, 256GB SSD. And we used Ubuntu 14.04 as OS, C\# 7.0 for our experiment. In this experiment, we are focused on grouping commercial IoT services by proposed classification algorithm.

We survey over 100 commercial IoT services. But there are too many low-level IoT services that perform only sensing and alert. We select 37 commercial services as an experimental set that performs its own processing. Fig. 5 shows proposed classification part on our platform.

We put the experimental set into proposed classification system. It classified into 19 groups. 10 groups of them that have more than one service. It proofs that each group is grouped together by their purpose. Remaining 9 groups contain single service. We think the reason is the absence of similar services. Table 6 to 10 shows the representative group by proposed classification algorithm.

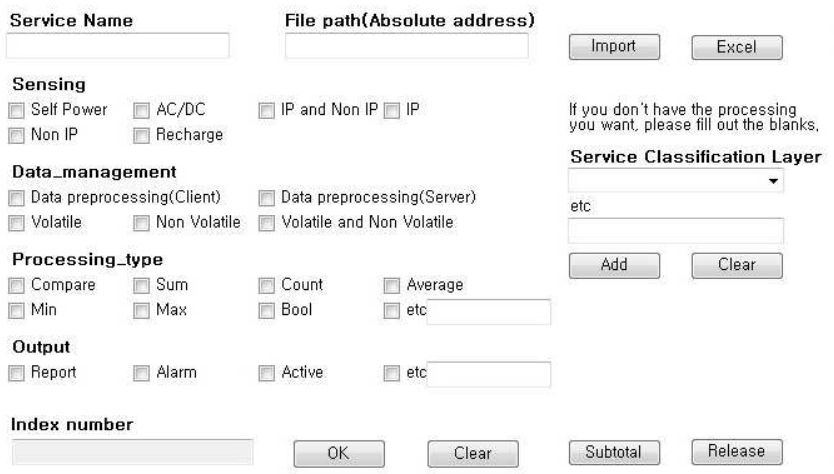

Fig. 5 Proposed classification system

TABLE VI

HEALTHCARE GROUP FOR MEDICINE

\begin{tabular}{|l|l|}
\hline Group ID & 0x88481080 \\
\hline Sensing & Self-power, Non-IP \\
\hline Data management & $\begin{array}{l}\text { Data preprocessing(server), } \\
\text { Non volatile }\end{array}$ \\
\hline Processing_type & Average, Threshold \\
\hline
\end{tabular}

\begin{tabular}{|c|c|c|c|}
\hline $\begin{array}{c}\text { Service_ } \\
\text { name }\end{array}$ & Explanation & Sensor specs & $\begin{array}{l}\text { Operation } \\
\text { Steps }\end{array}$ \\
\hline $\begin{array}{l}\text { Fitbit } \\
\text { Charge } \\
\text { HR }\end{array}$ & $\begin{array}{l}\text { Activity } \\
\text { Wristband }\end{array}$ & $\begin{array}{l}\text { PurePulse, All Day } \\
\text { Activity, SmartTrack, } \\
\text { Auto Sleep, Bluetooth }\end{array}$ & $\begin{aligned} & \text { sensing } \\
-> & \text { analysis } \\
-> & \text { report }\end{aligned}$ \\
\hline $\begin{array}{l}\text { Dexcom } \\
\text { _Sevenp } \\
\text { lus }\end{array}$ & $\begin{array}{l}\text { Glucose } \\
\text { monitoring }\end{array}$ & $\begin{array}{l}\text { Glucose, } 360 \text { degrees } \\
\text { of sensor }\end{array}$ & \begin{aligned} & \multicolumn{1}{c}{ sensing } \\
& -> analysis \\
& -> report \end{aligned} \\
\hline Lively & $\begin{array}{l}\text { Medical } \\
\text { Alert Watch }\end{array}$ & $\begin{array}{l}\text { Lively passive activity } \\
\text { Sensors }\end{array}$ & $\begin{aligned} & \text { sensing } \\
\rightarrow> & \text { analysis } \\
-> & \text { report }\end{aligned}$ \\
\hline
\end{tabular}


TABLE VII

HEALTHCARE GROUP FOR BODY

\begin{tabular}{|l|l|}
\hline Group ID & 0x88481480 \\
\hline Sensing & Self-power, Non-IP \\
\hline Data_management & $\begin{array}{l}\text { Data preprocessing(server), } \\
\text { Non volatile }\end{array}$ \\
\hline Processing_type & Average, Threshold(Max) \\
\hline
\end{tabular}

\begin{tabular}{|c|c|c|c|}
\hline $\begin{array}{l}\text { Service_ } \\
\text { name }\end{array}$ & Explanation & Sensor specs & $\begin{array}{c}\text { Operation } \\
\text { Steps }\end{array}$ \\
\hline Nuvant & $\begin{array}{l}\text { Healthcare_w } \\
\text { earable }\end{array}$ & $\begin{array}{l}\text { Temperature, } \\
\text { Heart rate, } \\
\text { Respiratory rate, } \\
\text { Motion Tracking }\end{array}$ & $\begin{aligned} & \text { sensing } \\
-> & \text { analysis } \\
-> & \text { report }\end{aligned}$ \\
\hline IT bra & $\begin{array}{l}\text { Healthcare_w } \\
\text { earable }\end{array}$ & $\begin{array}{l}\text { Novel } \\
\text { Sensor(Monitor } \\
\text { changes in the } \\
\text { temperature of a } \\
\text { cell }\end{array}$ & $\begin{aligned} & \text { sensing } \\
-> & \text { analysis } \\
-> & \text { report }\end{aligned}$ \\
\hline $\begin{array}{l}\text { Amp } \\
\text { strip }\end{array}$ & $\begin{array}{l}\text { Healthcare_w } \\
\text { earable }\end{array}$ & $\begin{array}{l}\text { ECG Sensor, } \\
\text { MEM's } \\
\text { accelerometer, } \\
\text { Skin temperature, } \\
\text { Bluetooth }\end{array}$ & $\begin{aligned} & \text { sensing } \\
-> & \text { analysis } \\
-> & \text { report }\end{aligned}$ \\
\hline
\end{tabular}

TABLE VIII

BABYCARE GROUP

\begin{tabular}{|l|l|}
\hline Group ID & 0x88481CC0 \\
\hline Sensing & Self-power, Non-IP \\
\hline Data_management & $\begin{array}{l}\text { Data preprocessing(server), } \\
\text { Non volatile }\end{array}$ \\
\hline Processing_type & Average,Threshold(Max,Min) \\
\hline
\end{tabular}

\begin{tabular}{|l|l|l|c|}
\hline $\begin{array}{c}\text { Service_n } \\
\text { ame }\end{array}$ & Explanation & \multicolumn{1}{|c|}{ Sensor specs } & $\begin{array}{c}\text { Operation } \\
\text { Steps }\end{array}$ \\
\hline $\begin{array}{c}\text { Owlet } \\
\text { Sock }\end{array}$ & $\begin{array}{l}\text { baby } \\
\text { monitoring }\end{array}$ & $\begin{array}{l}\text { Pulse Oximeter } \\
\text { w, Bluetooth }\end{array}$ & $\begin{array}{l}\text { sensing } \\
\text {->analysis } \\
\text {->report/ }\end{array}$ \\
\hline Sprouting & $\begin{array}{l}\text { baby } \\
\text { monitoring }\end{array}$ & $\begin{array}{l}\text { Heartrate, } \\
\text { Accelerometer }\end{array}$ & $\begin{array}{l}\text { sensing } \\
\text {->analysis } \\
\text {->report/ } \\
\text { alarm }\end{array}$ \\
\hline Mimo & $\begin{array}{l}\text { baby } \\
\text { monitoring }\end{array}$ & $\begin{array}{l}\text { Temperature, } \\
\text { Gyro, Bluetooth }\end{array}$ & $\begin{array}{l}\text { sensing } \\
\text {->analysis } \\
\text {->report/ } \\
\text { alarm }\end{array}$ \\
\hline
\end{tabular}

TABLE IX

HUMANLIFE GROUP

\begin{tabular}{|l|l|}
\hline Group ID & 0x88481EC0 \\
\hline Sensing & Self-power, Non-IP \\
\hline Data_management & $\begin{array}{l}\text { Data preprocessing(server), } \\
\text { Non volatile }\end{array}$ \\
\hline Processing_type & Average,Threshold(Max,Min),bool \\
\hline
\end{tabular}

\begin{tabular}{|c|c|c|c|}
\hline $\begin{array}{c}\text { Service_na } \\
\text { me }\end{array}$ & Explanation & Sensor specs & $\begin{array}{c}\text { Operation } \\
\text { Steps }\end{array}$ \\
\hline $\begin{array}{l}\text { Weatherflo } \\
\text { w_sky }\end{array}$ & $\begin{array}{l}\text { weather } \\
\text { monitoring }\end{array}$ & $\begin{array}{l}\text { Outdoor } \\
\text { temperature, } \\
\text { Humidity, } \\
\text { Barometric } \\
\text { pressure, Wind } \\
\text { speed, Wind } \\
\text { direction, Average } \\
\text { \& Gusts, } \\
\text { Lightning strikes, } \\
\text { Rain intensity, UV } \\
\text { index, Brightness, } \\
\text { Solar }\end{array}$ & $\begin{array}{l}\quad \text { sensing } \\
\text {->analysis } \\
\text {->report/ } \\
\text { alarm }\end{array}$ \\
\hline $\begin{array}{l}\text { Weatherflo } \\
\text { w_air }\end{array}$ & $\begin{array}{l}\text { weather } \\
\text { monitoring }\end{array}$ & $\begin{array}{l}\text { Air temperature, } \\
\text { Relative humidity, } \\
\text { Atmospheric } \\
\text { pressure } \\
\text { Lightning: strikes } \\
\text { \& distance, } \\
\text { Wireless }\end{array}$ & $\begin{array}{l}\text { sensing } \\
\text {->analysis } \\
\text {->report/ } \\
\text { alarm }\end{array}$ \\
\hline 8 cups & $\begin{array}{l}\text { weather } \\
\text { habitude } \\
\text { monitoring }\end{array}$ & $\begin{array}{l}\text { Weight, Wireless, } \\
\text { Bluetooth }\end{array}$ & $\begin{array}{l}\text { sensing } \\
\text {->analysis } \\
\text {->report/ } \\
\text { alarm }\end{array}$ \\
\hline
\end{tabular}

TABLE X

SMARTHOME GROUP

\begin{tabular}{|l|l|}
\hline Group ID & 0x90508220 \\
\hline Sensing & Self-power, Non-IP \\
\hline Data_management & $\begin{array}{l}\text { Data preprocessing(server), } \\
\text { volatile }\end{array}$ \\
\hline Processing_type & Compare,Bool \\
\hline
\end{tabular}

\begin{tabular}{|l|l|l|l|}
\hline $\begin{array}{l}\text { Service_ } \\
\text { name }\end{array}$ & Explanation & Sensor specs & $\begin{array}{l}\text { Operation } \\
\text { Steps }\end{array}$ \\
\hline $\begin{array}{l}\text { Amazon } \\
\text { Echodot }\end{array}$ & $\begin{array}{l}\text { voice } \\
\text { recognition } \\
\text { home secretary }\end{array}$ & $\begin{array}{l}\text { High-sensitivity } \\
\text { microphone }\end{array}$ & $\begin{array}{l}\text { sensing } \\
->\text { analysis } \\
->\text { active }\end{array}$ \\
\hline $\begin{array}{l}\text { Amazon } \\
\text { Echo }\end{array}$ & $\begin{array}{l}\text { voice } \\
\text { recognition } \\
\text { home secretary }\end{array}$ & $\begin{array}{l}\text { High sensitivity } \\
\text { microphone }\end{array}$ & $\begin{array}{l}\text { sensing } \\
->\text { analysis } \\
->\text { active }\end{array}$ \\
\hline $\begin{array}{l}\text { KT } \\
\text { Gienie }\end{array}$ & $\begin{array}{l}\text { voice } \\
\text { recognition } \\
\text { home secretary }\end{array}$ & $\begin{array}{l}\text { High sensitivity } \\
\text { microphone }\end{array}$ & $\begin{array}{l}\text { sensing } \\
->\text { analysis } \\
->\text { active }\end{array}$ \\
\hline $\begin{array}{l}\text { Google } \\
\text { Home }\end{array}$ & $\begin{array}{l}\text { voice } \\
\text { recognition } \\
\text { home secretary }\end{array}$ & $\begin{array}{l}\text { High-sensitivity } \\
\text { microphone }\end{array}$ & $\begin{array}{l}\text { sensing } \\
->\text { analysis } \\
->\text { active }\end{array}$ \\
\hline
\end{tabular}

\section{CONCLUSIONS}

While the IoT becomes a major issue of interest in both the academy and the industry, a solid foundation is still lacked for its rapid development. Various services are appeared such as smart homes, building management, surveillance services, smart farm, and so on. We focused on integrated IoT service platform that should be concerned with communication and interaction processes between different devices.

In this paper, to provide service similarity and module reusability, we propose classification algorithm that is based 
on detail operation 4 steps of IoT services. The first step is sensing step that classifies sensor devices. The second step is data management that classifies the preprocessing of data and maintenance of data. The third step is the processing step that divides and combine operation modules. The fourth step classifies IoT services into their own actions. To proof proposed classification algorithm, we sort 37 IoT services that perform its own processing from surveyed over 100 commercial IoT services. They are classified into 19 groups. The 10 groups of them that have more than one service. By experimental analysis, each group is grouped together by their purpose.

In this paper, our classification algorithm is based on service operation steps. In further works, we are going to study similarity based classification algorithm for sharing service modules and analysis data.

\section{ACKNOWLEDGMENT}

This research was supported by Basic Science Research Program through the National Research Foundation of Korea (NRF) funded by the Ministry of Science, ICT \& Future Planning (NRF-2016R1C1B1008330) and partly supported by Basic Science Research Program through the National Research Foundation of Korea (NRF) funded by the Ministry of Education (NRF-2016R1D1A1B03931602). *Corresponding Author: Daewon Lee (daelee@skuniv. ac.kr)

\section{REFERENCES}

[1] Nambi SAU, Sarkar C, Prasad RV, Rahim A, editors. A unified semantic knowledge base for IoT. Internet of Things (WF-IoT), 2014 IEEE World Forum on; 2014: IEEE.
[2] Fan YJ, Yin YH, Da Xu L, Zeng Y, Wu F. IoT-based smart rehabilitation system. IEEE transactions on industrial informatics. 2014;10(2):1568-77.

[3] Botta A, De Donato W, Persico V, Pescapé A, editors. On the integration of cloud computing and internet of things. Future Internet of Things and Cloud (FiCloud), 2014 International Conference on; 2014: IEEE.

[4] Perera C, Zaslavsky A, Christen P, Georgakopoulos D. Context aware computing for the internet of things: A survey. IEEE Communications Surveys \& Tutorials. 2014;16(1):414-54.

[5] Castro M, Jara AJ, Skarmeta AF, editors. An analysis of M2M platforms: challenges and opportunities for the Internet of Things. Innovative Mobile and Internet Services in Ubiquitous Computing (IMIS), 2012 Sixth International Conference on; 2012: IEEE.

[6] Lea R, Blackstock M, editors. City hub: A cloud-based iot platform for smart cities. Cloud Computing Technology and Science (CloudCom), 2014 IEEE 6th International Conference on; 2014: IEEE.

[7] Zhu Q, Wang R, Chen Q, Liu Y, Qin W, editors. Iot gateway: Bridgingwireless sensor networks into internet of things. Embedded and Ubiquitous Computing (EUC), 2010 IEEE/IFIP 8th International Conference on; 2010: IEEE.

[8] Thoma M, Meyer S, Sperner K, Meissner S, Braun T, editors. On iotservices: Survey, classification and enterprise integration. Green Computing and Communications (GreenCom), 2012 IEEE International Conference on; 2012: IEEE.

[9] Ganchev I, Ji Z, O'Droma M. A generic IoT architecture for smart cities. 2014

[10] Ning H, Hu S. Technology classification, industry, and education for Future Internet of Things. International Journal of Communication Systems. 2012;25(9):1230-41.

[11] Sammarco EC, Iera EA, De Capua EC. ENERGY EFFICIENT PROCEDURES FOR AN AUTONOMOUS INTERNET OF THINGS.

[12] Kelly SDT, Suryadevara NK, Mukhopadhyay SC. Towards the implementation of IoT for environmental condition monitoring in homes. IEEE Sensors Journal. 2013;13(10):3846-53.

[13] Kadhum AM, Hasan MK. Assessing the Determinants of Cloud Computing Services for Utilizing Health Information Systems: A Case Study. International Journal on Advanced Science, Engineering and Information Technology. 2017;7(2):503-10. 